\title{
Identification of Potential Areas to Develop Green Open Spaces (GOS) in Sub-District of Semampir Surabaya City, East Java Province
}

\author{
Moch Irfan Junaedhi \\ Student Master Programme of Urban Development \\ Management \\ Sepuluh Nopember Institute of Technology \\ Surabaya, Indonesia
}

\author{
Adji Pamungkas \\ Lecture Urban Development Management, \\ Faculty of Civil Engineering and Planning, \\ Sepuluh Nopember Institute of Technology \\ Surabaya, Indonesia
}

\author{
Eko Budi Santoso \\ Lecture Urban Development Management, \\ Faculty of Civil Engineering and Planning, \\ Sepuluh Nopember Institute of Technology \\ Surabaya, Indonesia
}

\begin{abstract}
Based on UU No. 26, tahun 2007 regarding the spatial arrangement of article 29, green open space consists of public green open space and private green open space. The proportion of green open space in the urban area is at least $\mathbf{3 0}$ (thirty) percent of the total city area. It consists of 20 (twenty) percent for the public green open space and 10 (ten) percent for private open space. About, the distribution of green open space in urban areas, it's adjusted to the population distribution and service hierarchy with respect to space plans and patterns.

The environmental problems caused by the conversion of the green open space must be overcome immediately by optimizing the provision of urban green space in Sub-District of Semampir both in quality and quantity, improving institutional coordination, improving the quality of human resources and involving stakeholders in the implementation of green open space.

Therefore, related to the above background exposure is required to research how to optimize the provision of green open space in Semampir Sub-District Surabaya. As an early stage in the process of optimization, it is necessary to identify areas that have the potential to develop green open space in Sub-District of Semampir, Surabaya City.
\end{abstract}

Keywords-component; potential area to develop green open space. (GOS)

\section{INTRODUCTION}

The development of a city is influenced by economic development and policy. This is due to the development of the city is basically a physical form of economic development. Some aspects that can determine the growth and development of a city, namely population development, completeness of facilities and level of investment (Reksohadiprojo, 2001).

Based on data from the Environment Agency, 2014, the green open space for Sub-District of Semampir is 1.3 Ha or $0.15 \%$ of the total area. Based on the regulation, green open space of urban area is $30 \%$ so that to fulfill the requirement of green open space according to regulation for Semampir area need $261,48 \mathrm{Ha}$ or $29,85 \%$. It means that to reach the target of green open space by 30\% Sub-District of Semampir still needs to provide the land as green open space. It means that the existence of open urban green space has not been managed maximally because of the limited area in Sub-District of Semampir.

Environmental problems caused by the conversion of green space must be overcome by optimizing the provision of urban green space in Sub-District of Semampir, both quantitatively and qualitatively, improving institutional coordination, improving the quality of human resources and involving stakeholders in the implementation of green open space. Therefore, related to the background exposure above is required research how to optimize the provision of green open space in urban areas in Sub-District of Semampir, Surabaya city.

Green open space plays a big role in improving environmental quality. Together with the development of urban, negative impacts arises, specially built land (settlements and activities) that resulted in environmental degradation so that non-built land (open land) becomes reduced. The proportion of GOS in Sub-Distric Semampir is only $0.15 \%$ of the total area, so it takes $261,48 \mathrm{Ha}$ or $29,85 \%$.

But because of the limited area, it is necessary to optimize the providing of the open green area in Sub-District of Semampir in order to improve the decreasing of environmental quality.

\section{METHODOLOGY}

Before determining areas that have the potential to be developed, it needs to do overlay land suitability with some maps. The basis used in the reclassification refers to the analysis of the basic physical and environmental aspects (Ministerial Decree No. 20 / PRT / M / 2007). This stage is an analysis used to determine the value of the ability and suitability of a region's land. 


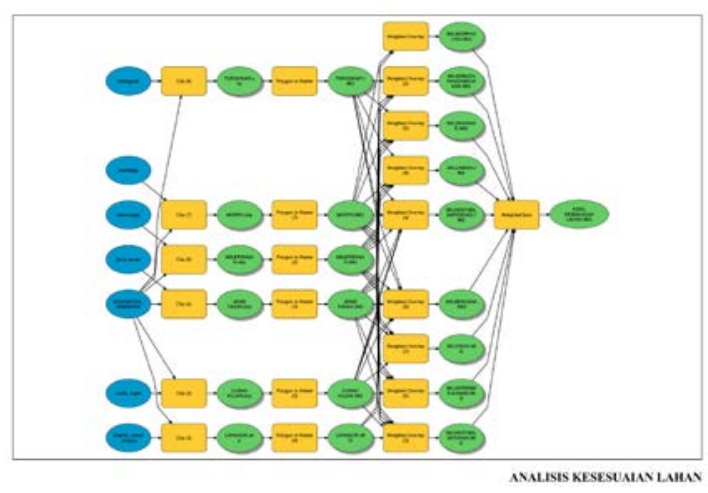

Fig 1 Overlay Process

Sumber : Penulis, 2018

\section{RESULT AND DISCUSSION}

\section{A. WATER AVAILABILITY}

Based on the Regulation of the Minister of Public Works No.20 / Art / M / 2007 Technical Guidance of Physical and Environmental Aspect Analysis, Economics, and SocioCulture in Spatial Planning, the following results are obtained:

\section{TABLE I.WEIGHTVALUEOF WATER AVAILABILITY} IN SUB-DISTRICT OF SEMAMPIR

\begin{tabular}{|c|l|c|c|c|}
\hline No & Little District & rainfall & score & Category \\
\hline 1 & Ampel & $1500-1750$ & 3 & $\begin{array}{c}\text { Medium water } \\
\text { availability }\end{array}$ \\
\hline 2 & Sidotopo & $1500-1750$ & 3 & $\begin{array}{c}\text { Medium water } \\
\text { availability }\end{array}$ \\
\hline 3 & Pegirian & $1500-1750$ & 3 & $\begin{array}{c}\text { Medium water } \\
\text { availability }\end{array}$ \\
\hline 4 & Wonokusumo & $1500-1750$ & 3 & $\begin{array}{c}\text { Medium water } \\
\text { availability }\end{array}$ \\
\hline 5 & Ujung & $1500-1750$ & 3 & $\begin{array}{c}\text { Medium water } \\
\text { availability }\end{array}$ \\
\hline
\end{tabular}

Source: Data eksisting peta Kota Surabaya,2014

Based on existing data, rainfall in Sub-District of Semampir is $1500-1750 \mathrm{~mm} /$ year. We see that the rainfall in the study area has a score of 3 . Score 3 is included in the category of medium water availability. The availability of water is important for continuity of green open space, where the utilization of this space will require water

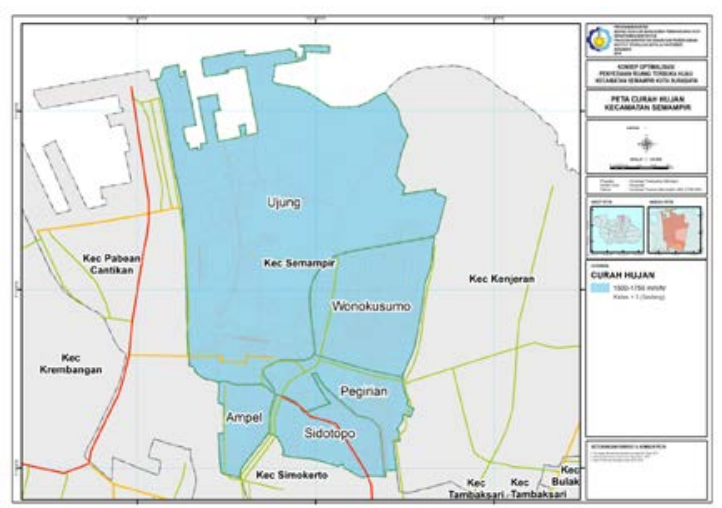

Fig 2. Weight Value Availability of Water in Sub-District Semampir

\section{B. TYPE OF SOIL}

TABLE II. THE VALUE OF SOIL TYPE AND WORKABILITY IN SUB-DISTRICT OF SEMAMPIR

\begin{tabular}{|c|l|c|c|c|}
\hline No & Little District & Type of Soil & Score & Category \\
\hline 1 & Ampel & Alluvial & 5 & high workability \\
\hline 2 & Sidotopo & Alluvial & 5 & high workability \\
\hline 3 & Pegirian & Alluvial & 5 & high workability \\
\hline 4 & Wonokusumo & Alluvial & 5 & high workability \\
\hline 5 & Ujung & Alluvial & 5 & high workability \\
\hline
\end{tabular}

Source: Data existing Peta Kota Surabaya,2014

Based on the existing data type of land in Sub- District of Semampir is Alluvial. The type of soil in the study area has a score of 5 . This score of 5 will facilitate the planting process in the provision of green space because it has moderate to high soil fertility.

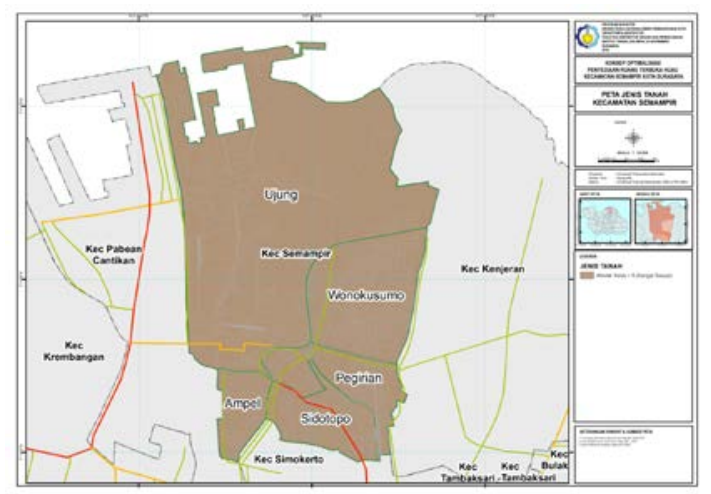

Fig 3. The Result of soil type in Sub-District Semampir

\section{SLOPES STABILITY}

TABLE III. WEIGH VALUE OF SLOPE AND SLOPE STABILITY IN SUB-DISTRICT SEMAMPIR

\begin{tabular}{|l|l|l|l|l|}
\hline No & Little District & \multicolumn{1}{|c|}{ slope } & Score & Category \\
\hline 1 & Ampel & $>45 \%$ & 5 & High slope stability \\
\hline 2 & Sidotopo & $25-45 \%$ & 5 & High slope stability \\
\hline 3 & Pegirian & $15-25 \%$ & 5 & High slope stability \\
\hline 4 & Wonokusumo & $2-15 \%$ & 5 & High slope stability \\
\hline 5 & Ujung & $0-2 \%$ & 5 & High slope stability \\
\hline
\end{tabular}

Source: Data eksisting peta Kota Surabaya,2014

Based on existing data slopes in Sub-District of Semampir is $0-2 \%$. This slope condition has a value of 5 with a high slope stability category. This high slope stability will support the process of building a green open space because it is a safe area for the development process.

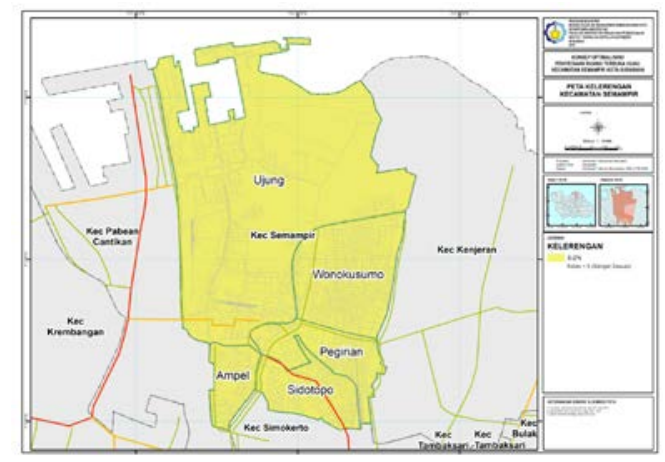

Fig 4. Weight Value Type of Soil in Sub-District of Semampir 


\section{NATURAL DISASTER}

TABLE IV. WEIGHT VALUE OF NATURAL DISASTERS IN SUB-DISTRICT OF SEMAMPIR

\begin{tabular}{|c|c|c|c|c|}
\hline No & Little District & Slope & Score & Category \\
\hline 1 & Ampel & $>45 \%$ & 5 & \multirow{2}{*}{$\begin{array}{l}\text { High Natural Disaster } \\
\text { Potential }\end{array}$} \\
\hline 2 & Sidotopo & $25-45 \%$ & 5 & \\
\hline 3 & Pegirian & $15-25 \%$ & 5 & $\begin{array}{l}\text { High Natural Disaster } \\
\text { Potential }\end{array}$ \\
\hline 4 & Wonokusumo & $2-15 \%$ & 5 & \multirow{2}{*}{$\begin{array}{l}\text { High Natural Disaster } \\
\text { Potential }\end{array}$} \\
\hline 5 & Ujung & $0-2 \%$ & 5 & \\
\hline
\end{tabular}

Source: Data existing Peta Kota Surabaya,2014

Based on existing data slopes in the Sub- District of Semampir is $0-2 \%$. This slope condition has a value of 5 with a potential category of less natural disasters or can be called safe because it has a score of 5 . Results from basic physical conditions that are relatively safe against potential hazards, it will provide convenience in the process of providing green space in the research area

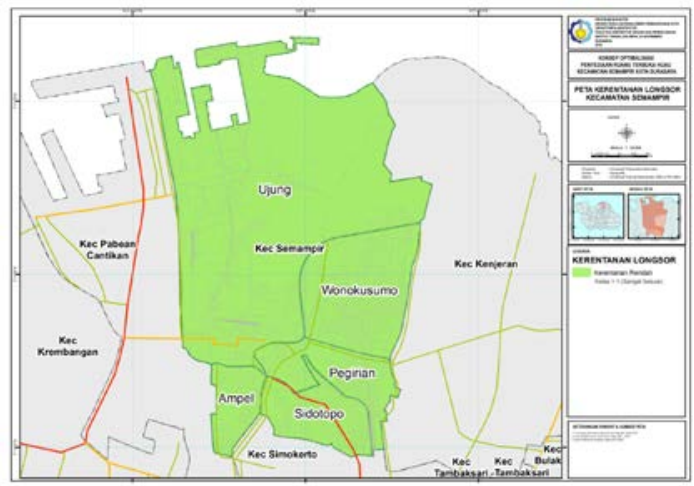

Picture 5. Result of soil Type in Sub-District of Semampir

E. MORPHOLOGY

TABLE V. VALUE MORPHOLOGY WEIGHT IN SUBDISTRICT OF SEMAMPIR

\begin{tabular}{|c|c|r|c|l|}
\hline No & Little District & Slope & Score & \multicolumn{1}{|c|}{ Category } \\
\hline 1 & Ampel & $>45 \%$ & 5 & $\begin{array}{l}\text { Low land capability } \\
\text { from morphology }\end{array}$ \\
\hline 2 & Sidotopo & $\begin{array}{r}25-45 \\
\%\end{array}$ & 5 & $\begin{array}{l}\text { Low land capability } \\
\text { from morphology }\end{array}$ \\
\hline 3 & Pegirian & $\begin{array}{r}15-25 \\
\%\end{array}$ & 5 & $\begin{array}{l}\text { Low land capability } \\
\text { from morphology }\end{array}$ \\
\hline 4 & \multicolumn{5}{|c|}{ Wonokusumo } & $\begin{array}{r}2-15 \\
\%\end{array}$ & 5 & $\begin{array}{l}\text { Low land capability } \\
\text { from morphology }\end{array}$ \\
\hline
\end{tabular}

SKL Morphology means landscape, the ability of land from high morphology means the morphological conditions of a complex area. Complex morphology means that the landscape is in the form of mountains, mountains, hills, and waves. As a result, the ability to develop is very low so that it is difficult to develop and or is not feasible to develop. Such land should be recommended as protected or culturally that unrelated to human.

Based on existing data the slope in theSub-District of Semampir is $0-2 \%$ so that it is included in the sloping plain morphology. This condition with morphology has a value of 5 with a land capability category of low morphology. Because it is included in the land capability category of low morphology, the provision of land for green space can be said to be appropriate because this region is relatively low in slope.

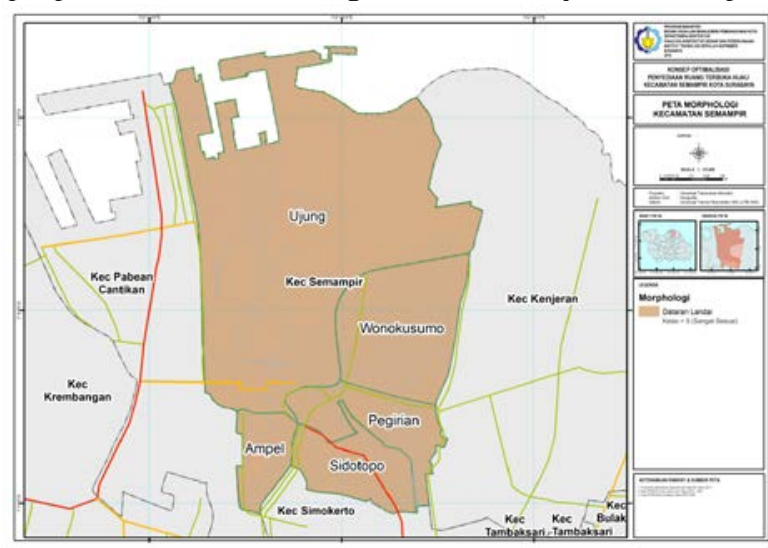

Fig 6. The Result of Soil Type in Sub-District Semampir

\section{F. EASE TO WORK ON}

TABLE 6. VALUE WEIGHT EASE OF DOING IN DISTRICT SEMAMPIR

\begin{tabular}{|c|c|c|c|c|}
\hline No & Little District & height & score & category \\
\hline 1 & Ampel & $\begin{array}{c}2500-3672 \\
\mathrm{~m}\end{array}$ & 5 & high workability \\
\hline 2 & Sidotopo & $\begin{array}{c}1500-2500 \\
\mathrm{~m}\end{array}$ & 5 & high workability \\
\hline 3 & Pegirian & $\begin{array}{c}500-1500 \\
\mathrm{~m}\end{array}$ & 5 & high workability \\
\hline 4 & Wonokusumo & $100-500 \mathrm{~m}$ & 5 & high workability \\
\hline 5 & Ujung & $0-100 \mathrm{~m}$ & 5 & high workability \\
\hline
\end{tabular}

Source: Data existing Peta Kota Surabaya,2014

Based on topographic data in the Sub-District of Semampir is $0-100 \mathrm{mdpl}$. Based on this condition can be classified category ease of working high with value 5. Land with category Convenience of this high work is very supportive of the supply of green open space because the existing land makes it easy to do.

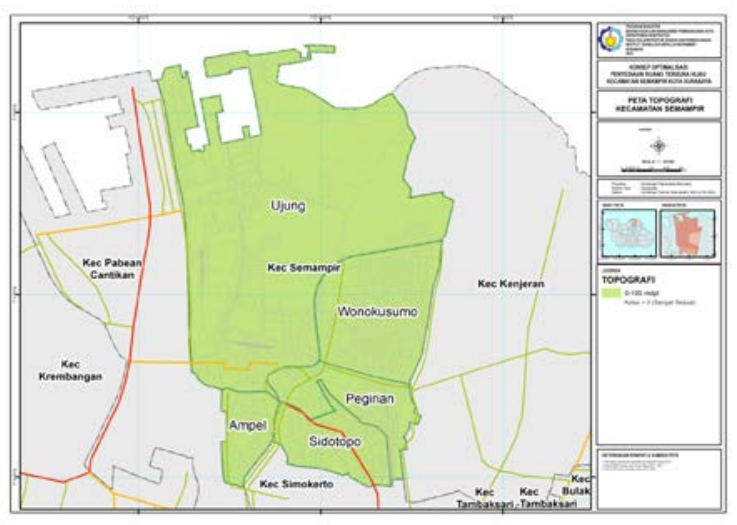

Fig 7. Existing topographic maps in Semampir Subdistrict

FuGOSermore, the maps that have been described are reclassified according to the categories in accordance with the guidelines of the land suitability analysis. Followed by an overlay process to determine the suitability of land for green 
open spaces. The process of spatial analysis performed can be seen in the picture below:

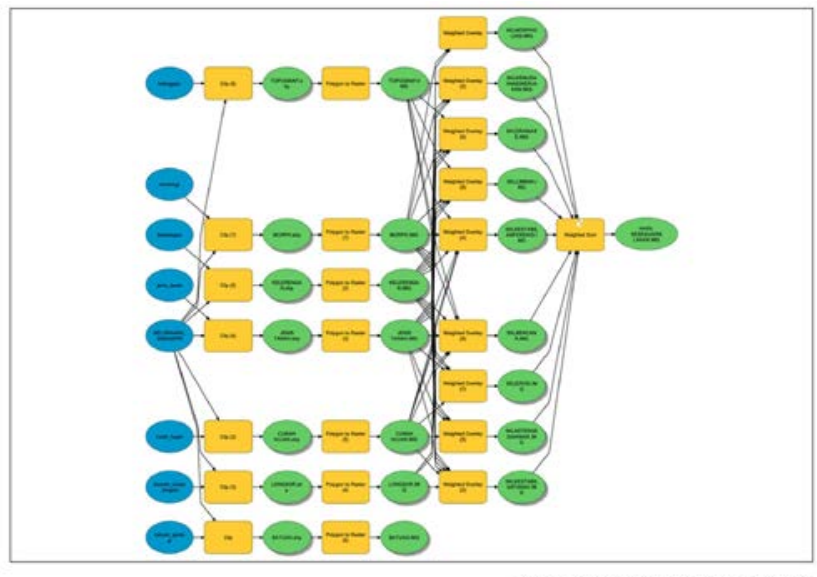

Fig 8 . The reclassification process model in land suitability analysis for green space

The following is the result of land suitability analysis for green open space based on basic physical condition. The basic physical conditions used in this analysis process are height, morphology, slope, soil type, rainfall, landslide-prone areas. Land suitability is only Ujung Dan Wonokusumo Urban Village. Most of Sub-District of Semampir is physically not suitable, consisting of Ampel Village, Pegirian Village, and Sidotopo Village.

TABLE VII. LAND SUITABILITY ANALYSIS RESULTS BASED ON LAND SUITABILITY IN SUB-DISTRICT OF SEMAMPIR

\begin{tabular}{|c|c|c|c|c|}
\hline No & Little District & suitable & unsuitable & Total \\
\hline 1 & Ujung & 567,14 & 0 & 567,14 \\
\hline 2 & Sidotopo & 67,81 & 0 & 67,81 \\
\hline 3 & Wonokusumo & 136,73 & 0 & 136,73 \\
\hline 4 & Pegirian & 71,67 & 0 & 71,67 \\
\hline 5 & Ampel & 40,53 & 0 & 40,53 \\
\hline \multicolumn{2}{|r|}{ Total } & 883,88 & 0 & 883,88 \\
\hline
\end{tabular}

Source: dianalisa berdasarkan data kondisi existing 2016

Based on the result of the overlay that is done to see the suitability area for the green open space, basic physical of all area are suitable to be used for providing open green space. Basic physical conditions that are taken into consideration in the land suitability analysis are rainfall maps, soil type maps, slope maps, vulnerability maps, morphological maps, and topographic maps. Sub-District of Semampir has rainfall conditions of $1500-1750 \mathrm{~mm}$ / year, so it has a score of 3 and is included in the category of adequate water availability

. Type of land in the Sub-District of Semampir is Alluvial, so it has a score of 5 and classified as high ease of doing. Slopes in the District of Semampir is $0-2 \%$. This slope condition has a value of 5 with a high slope stability category. In addition, the slope in the Sub-District of Semampir potential categories or can be called safe because it has a score of 5 .

By knowing the slope in the Sub-District of Semampir area is $0-2 \%$ so that it is included in the sloping plain morphology.
This condition with morphology has a value of 5 with a land capability category of low morphology. Topography in SubDistrict of Semampir is 0-100mdpl. Based on this condition, it can be classified as a category of ease of work with a value of 5. Overall is classified as suitable.

Suitability of Ujung Village 567.14 Ha, Sidotopo Village 67.81 Ha, Wonokusumo Village $136.73 \mathrm{Ha}$, Pegirian Village $71.67 \mathrm{Ha}$, and Ampel Village 40.53 Ha. For more details can be seen on the map below.

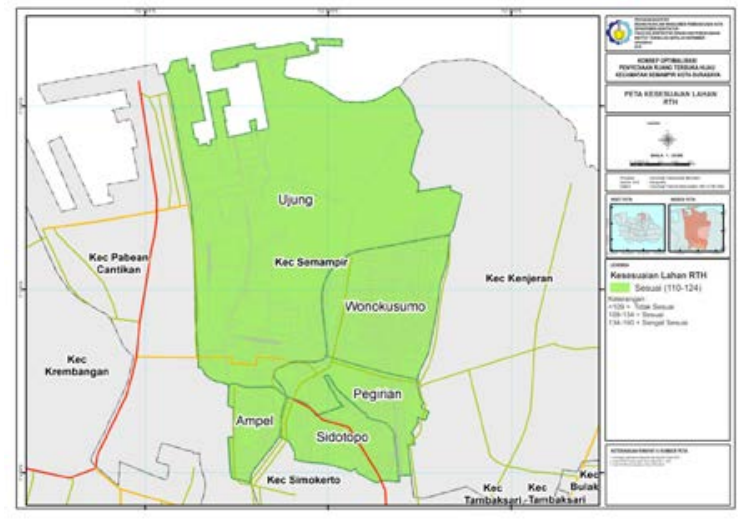

Fig 9. Land suitability map for green space based on the basic physical conditions of Semampir Subdistrict

\section{DETERMINATION OF GOS POTENTIAL AREAS}

To determine the area of potential green open space in Sub-District of Semampir, in addition to considering the suitability of the land discussed earlier, also consider the potential of other green open spaces, namely the potential for green space generated from buffers from road borders, river borders and railroad borders and land of government assets in the region research and spatial plan of Spatial Plan of 2012. The following will be explained related to GOS river border.

\section{BUFFER GOS WATER RIVER}

The demarcation line is the outline of the safety boundary to erect a building and / or fence that is drawn at a certain distance parallel to the road axle, the outer edge of the bridgehead, river bank, channel edge, embankment, edge / swamp, reservoir edge, edge of spring, axle railroad tracks, power lines, gas pipelines.

Based on the Regulation of the Minister of Public Works and Public Housing of the Republic of Indonesia Number 28 / PRT / M / 2015 concerning the Determination of the River Border Line and the Lake Border Line Article 4 paragraph (2) letter a borderline on a river not bearing in an urban area is determined at least within 10 (ten) meters of the left and right edges of the riverbed along the river channel, in terms of the depth of the river less than or equal to 3 (three) meters. Here is an illustration of the potential buffering process of GOS river border.

Based on the previous explanation, for the study area at the buffering process, a distance of $10 \mathrm{~m}$ will be given.

\section{BUFFER GOS RAILROAD BORDER}

Determination of railroad border buffers using consideration of PU Ministerial Regulation Number 5 of 2008 concerning Guidelines for Provision and Utilization of Green 
Open Space in Urban Areas, provision of green open space on the border of railroad tracks is a green space that has the main function to limit the interaction between community activities and railroad train. In this regard, it is necessary to firmly determine the width of the railroad line in urban areas.

TABLE VIII. WIDTH OF RAILROAD BORDER LINE

\begin{tabular}{|l|c|c|}
\hline \multicolumn{1}{|c}{ Railroads } & \multicolumn{2}{c|}{ Object } \\
\cline { 2 - 3 } & Plants & Building \\
\hline a. Straight railroad & $>11 \mathrm{~m}$ & $>20 \mathrm{~m}$ \\
\hline b. archway railroad & $>23 \mathrm{~m}$ & $>23 \mathrm{~m}$ \\
\hline - inner archway railroad & & $>11 \mathrm{~m}$ \\
\hline - outer archway railroad & $>11 \mathrm{~m}$ & $>$ \\
\hline
\end{tabular}

Source: Permen PU Nomor 5 Tahun 2008 tentang Pedoman Penyediaan dan Pemanfaatan Ruang Terbuka Hijau di Kawasan Perkotaan

There are other regulations related to rail border namely Law No. 23 of 2007 Concerning Article 42 paragraph 1 explains that the boundary of space belonging to the railway line is the space on the left and right side of the railway utility room which is the widest width of 6 (six) meters, while in Article 45 the boundary of the railway monitoring space is space on the left and right sides of the space belonging to the widest railway line 9 (nine) meters wide. Here is an illustration of the potential buffering process of GOS border railroads

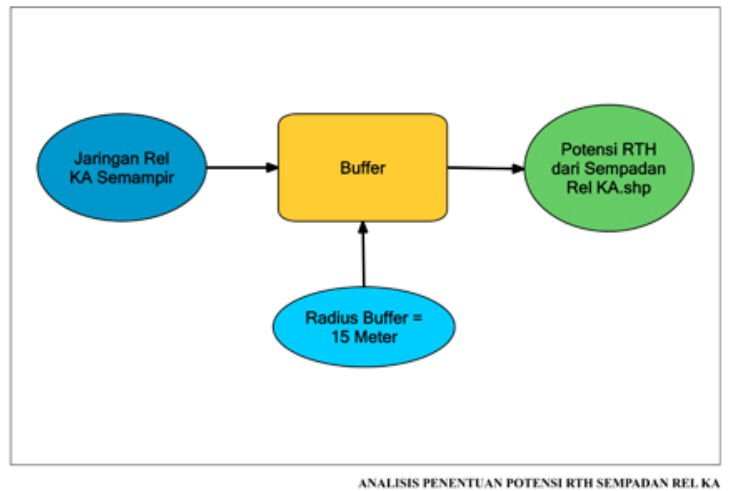

Based on the existing conditions in the study area is a solid and built location and consider the safety of the community from the activities of railway activities, then taken the middle value of both regulations that provide buffer $15 \mathrm{~m}$.

\section{BUFFER GOS BORDER OF ROAD}

PU Ministerial Regulation Number 5 the Year 2008 concerning Guidelines for Provision and Utilization of Green Open Space in Urban Areas explains that for green roads, green open space can be provided by placing plants between $20-30 \%$ of the space owned by the road (rumija) in accordance with the road class.

To determine the type of plant selection, it is necessary to pay attention to 2 (two) things, namely the function of the plant and the requirements for placement.

Based on Surabaya Mayor Regulation No. 39 of 2012 on Guidelines and Technical Standards for Service of Use of Room 15, In areas where no Spatial Plan concept and spatial licensing service services have ever been published, in general the GOS on environmental roads shall be at least $3 \mathrm{~m}$ (three meter). On existing roads less than $2 \mathrm{~m}$ (two meters) and located in densely populated villages, the GOS considers field conditions. In an unplanned location, if there is a planned channel of more than 8 (eight) meters (including wet and dry cross-sections), it is necessary to specify a GOS that serves as a river border or inspection road of at least $3 \mathrm{~m}$ (three meters) side or consider the spatial plan and surrounding conditions. Here is an illustration of potential GOS path buffering process.

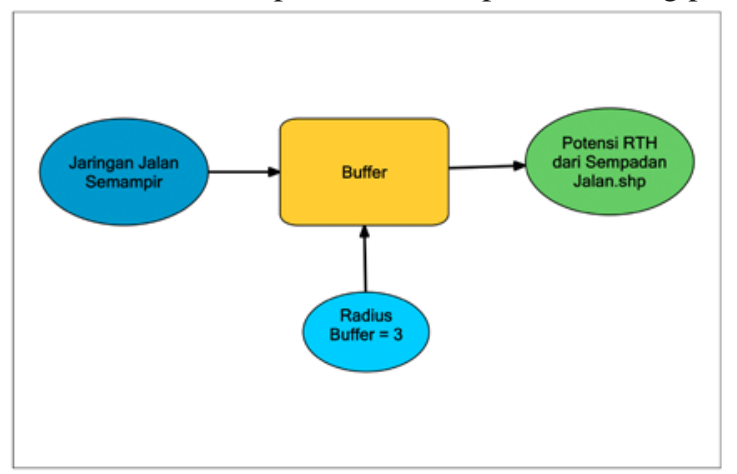

Based on the previous explanation then, for the research area at the stage of the buffering process will be given a distance of $3 \mathrm{~m}$. After the overall buffering is described, the following is the result of the buffering being performed.

Result of buffering and overlay

Based on the previous explanation is the process of analysis conducted to determine the potential of GOS by providing buffering on the GOS border. The results obtained from this buffering analysis will be followed by prsoses overlapping the overall potential of GOS. For more details will be explained regarding the buffering results.

\section{Buffering}

After buffering the road border, river and railroad border, overlaying the asset map and planning a pattern of space patterns. This overlay was carried out to identify all potential green open spaces in Semampir Subdistrict, as well as remain in line with the planned space pattern in the city, especially the plan for the allocation of green open spaces. For more details, will be described the overall overlay process through the model builder below.

TABLE IX. RESULTS OF BUFFERING AREA OF SEMPADAN GREEN OPEN SPACE IN SEMAMPIR SUBDISTRICT

\begin{tabular}{|c|l|c|c|c|c|c|c|}
\hline \multirow{2}{*}{ No } & \multicolumn{1}{|c|}{$\begin{array}{c}\text { Potensi } \\
\text { Area GOS }\end{array}$} & Ampel & $\begin{array}{c}\text { Pegiri } \\
\text { an }\end{array}$ & $\begin{array}{c}\text { Sidotop } \\
\text { o }\end{array}$ & $\begin{array}{c}\text { Uju } \\
\text { ng }\end{array}$ & $\begin{array}{c}\text { Wono } \\
\text { kusum } \\
\text { o }\end{array}$ & Total \\
\cline { 3 - 7 } & $\begin{array}{l}\text { Potensi } \\
\text { GOS dari } \\
\text { Sempadan } \\
\text { Jalan }\end{array}$ & 3,16 & 2,29 & 3,94 & $\begin{array}{c}19,2 \\
6\end{array}$ & 8,48 & 37,13 \\
\hline 2 & $\begin{array}{l}\text { Potensi } \\
\text { GOS dari } \\
\text { Sempadan } \\
\text { Rel KA }\end{array}$ & 0,00 & 3,27 & 1,53 & 4,38 & 0,00 & 9,18 \\
\hline $\begin{array}{l}\text { Potensi } \\
\text { GOS dari } \\
\text { Sempadan } \\
\text { Sungai }\end{array}$ & 0,00 & 0,62 & 0,00 & $\begin{array}{c}10,8 \\
2\end{array}$ & 0,30 & 11,74 \\
\hline \multicolumn{2}{|l}{ Jumlah } & 3,16 & 6,18 & 5,47 & $\begin{array}{c}34,4 \\
6\end{array}$ & 8,78 & 58,05 \\
\hline
\end{tabular}

Source: Hasil Analisa, 2018 
Based on the analysis that has been done, the widest GOS potential is Ujung Village with an area of 34.46 Ha. The GOS potential of the widest road border is Ujung Village area of 19.26 Ha. The GOS potential of the largest railway line is Ujung with an area of $4.38 \mathrm{Ha}$. The GOS potential of the widest river boundary is Ujung Village with an area of 34.46 Ha. Overall Ujung Urban Village is the widest area of potential GOS. For the district with the widest area of the lowest GOS is Ampel District with an area of 3.16 Ha. Little District Ampel only has the potential of GOS coming from the Potential of GOS from the Road Border. After this process is done, the overall overlay process is potential to get the GOS area. For this reason, an overlay step is needed.

\section{AREA MAPPING IS POTENTIALLY USED AS GREEN OPEN SPACE}

Based on the above model, this overlay process is carried out in the early stages of finding the suitability of land for the use of green open space, then the buffering process is determined from the potential of green open space borders of roads, railroads and river boundaries with each boundary in accordance with the relevant rules. For example for GOS path specified buffer $3 \mathrm{~m}$, while for railway specified buffer $15 \mathrm{~m}$ while for river border given $10 \mathrm{~m}$ buffer. The result of the buffer yields a potential map of the GOS of the Border of the road, the GOS Potential of the Rails of the Rel, and the Potential GOS of the River Border. Of the four potential map results (GOS land suitability map of Semampir Subdistrict, road border GOS potential map, railroad border GOS potential map, and river border GOS Potential Map), an overlay is performed with a map of government assets in the study area, as well as a spatial plan map 2012. For more details will be explained related Asset government.

\section{Government Asset Mapping}

Based on asset data of Surabaya City Building and Land Management Office Year 2018, Asset Land Area in SubDistrict of Semampir is 72,45 Ha. Soil. For more details can be seen in the table below.

TABLE X. THE LAND AREA OF ASSETS BASED ON THE URBAN VILLAGE OF SUB-DISTRICT OF SEMAMPIR

\begin{tabular}{|c|l|c|}
\hline No & \multicolumn{1}{|c|}{ Little District } & $\begin{array}{c}\text { Land Area of Assets } \\
(\mathrm{Ha})\end{array}$ \\
\hline 1 & Ampel & 0 \\
\hline 2 & Pegirian & 17,82 \\
\hline 3 & Sidotopo & 18,82 \\
\hline 4 & Ujung & 22,02 \\
\hline 5 & Wonokusumo & 13,79 \\
\hline \multicolumn{2}{|c|}{ Total } & 72,45 \\
\hline
\end{tabular}

Source: Data aset Dinas Pengelolan Bangunan dan Tanah Pemkot Surabaya, 2018

For more details, the distribution of assets of Surabaya City, especially Sub-District of Semampir, can be seen on the map as follows.

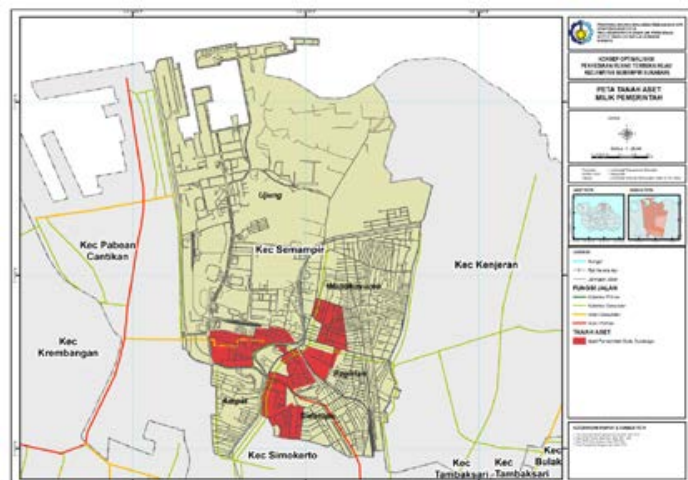

Picture10. Map of Semampir District assets

\section{Space Pattern Plan}

Land Utilization Plan in Sub-District of Semampir is generally almost uniform in every Little District. Most of the land use in every urban village is dominated by settlements (wake land). In some sub-districts in Sub-District of Semampir, there are still empty land and fishery land (tambaks) such as in Ujung Sub-district. Based on the spatial pattern plan, land use can be seen as land use based on the Little District as follows:

TABLE X1. LAND USE PLAN BASED ON SUBDISTRICTS OF SUB-DISTRICT OF SEMAMPIR

\begin{tabular}{|l|c|c|c|c|c|c|}
\hline SPATIAL PLAN & Ampel & Pegirian & Sidotopo & Ujung & $\begin{array}{c}\text { Wonokusum } \\
\text { o }\end{array}$ & $\begin{array}{c}\text { Total } \\
(\mathrm{Ha})\end{array}$ \\
\hline Public Facility & 3,27 & 2,19 & 3,76 & 1,92 & 0,00 & 11,14 \\
\hline $\begin{array}{l}\text { Industry and } \\
\text { Storages }\end{array}$ & 0,00 & 0,00 & 0,00 & 65,83 & 2,51 & 68,34 \\
\hline Road/Way & 8,98 & 8,50 & 13,80 & 59,48 & 25,39 & 116,16 \\
\hline Army & 0,00 & 0,00 & 0,00 & 379,03 & 0,00 & 379,03 \\
\hline $\begin{array}{l}\text { Trade and } \\
\text { Services }\end{array}$ & 6,35 & 2,58 & 3,71 & 0,37 & 3,03 & 16,03 \\
\hline Sattlement & 20,19 & 56,74 & 46,54 & 36,71 & 101,66 & 261,83 \\
\hline $\begin{array}{l}\text { Open Green } \\
\text { Space }\end{array}$ & 0,00 & 0,84 & 0,00 & 11,45 & 0,00 & 12,28 \\
\hline River & 1,75 & 0,83 & 0,00 & 8,84 & 4,15 & 15,56 \\
\hline Ponds & 0,00 & 0,00 & 0,00 & 3,52 & 0,00 & 3,52 \\
\hline Total (Ha) & 40,53 & 71,67 & 67,81 & 567,14 & 136,73 & 883,88 \\
\hline
\end{tabular}

Source: RTRW Kota Surabaya, 2012

The area of green space based on the Surabaya City Spatial Plan in 2012, can be seen only having an area of $1.4 \%$ of the total area. If based on the standard of meeting the urban open space which is $30 \%$ of the total area, then the green open space is still relatively minimal in the study area. FuGOSermore, it will discuss the mapping of green space on open land that has not been used as green open space

\section{GOS Potential Mapping on open land that has not been used as green open space}

Open space is the spaces within the city or a wider area either in the form of area / area or in the form of elongated areas / paths wherein its use is more open that basically without a building. Open space consists of green open space and non-green open space. Sub-District of Semampir has open potential land for use as green open space. For more details can be seen in the table and the map below. 
TABLE XII. THE POTENTIAL AREA OF OPEN LAND THAT HAS NOT BEEN USED AS GOS IN SUB-DISTRICT OF SEMAMPIR

\begin{tabular}{|l|c|c|c|c|c|c|}
\hline $\begin{array}{c}\text { Potentials } \\
\text { of GOS }\end{array}$ & $\begin{array}{c}\text { Ampe } \\
\text { l }\end{array}$ & $\begin{array}{c}\text { Pegiri } \\
\text { an }\end{array}$ & $\begin{array}{c}\text { Sidotop } \\
\text { o }\end{array}$ & $\begin{array}{c}\text { Ujun } \\
\mathrm{g}\end{array}$ & $\begin{array}{c}\text { Wonokusu } \\
\text { mo }\end{array}$ & $\begin{array}{c}\text { Total } \\
\text { (Ha) }\end{array}$ \\
\hline $\begin{array}{l}\text { open area } \\
\text { that has not } \\
\text { be used as } \\
\text { open green } \\
\text { space }\end{array}$ & 0,40 & 4,45 & 1,64 & $\begin{array}{c}89,0 \\
0\end{array}$ & 0,24 & 95,75 \\
\hline
\end{tabular}

Source: diolah dari peta eksisting dan perhitungan peta, 2018

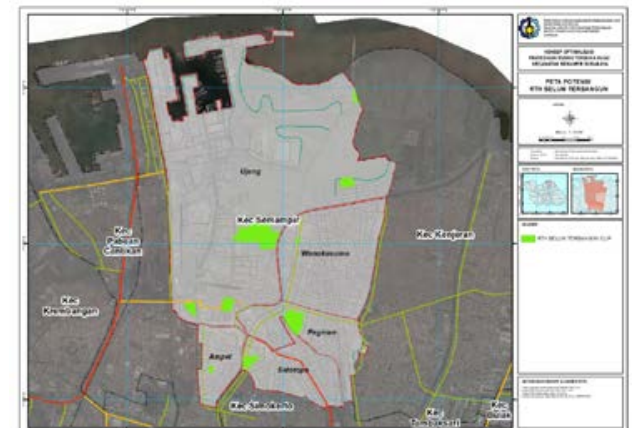

Fig 11. Map oг potentıa open green space open space tnat nas not been used as a green space for Semampir District

From the process that has been done previously obtained the result of the overall overlay to determine the the potency of GOS as follows:

TABLE XIII. EXTENT OF THE POTENTIAL AREA DEVELOPED BY GOS IN SUB-SUB-DISTRICT OF SEMAMPIR

\begin{tabular}{|c|c|c|c|c|c|c|c|}
\hline \multirow[b]{2}{*}{$\begin{array}{l}N \\
0\end{array}$} & \multirow[b]{2}{*}{$\begin{array}{c}\text { Potensi } \\
\text { Area GOS }\end{array}$} & \multicolumn{5}{|c|}{ Little District } & \multirow[b]{2}{*}{$\begin{array}{l}\text { Total } \\
\text { (Ha) }\end{array}$} \\
\hline & & $\begin{array}{l}\text { Am } \\
\text { pel }\end{array}$ & $\begin{array}{l}\text { Pegiri } \\
\text { an }\end{array}$ & $\begin{array}{l}\text { Sidoto } \\
\text { po }\end{array}$ & $\begin{array}{c}\text { Ujun } \\
\text { g }\end{array}$ & $\begin{array}{c}\text { Wono } \\
\text { kusum } \\
\text { o }\end{array}$ & \\
\hline 1 & $\begin{array}{l}\text { Potential } \\
\text { area of RPH } \\
\text { at the border } \\
\text { way }\end{array}$ & 3,16 & 2,29 & 3,94 & 19,26 & 8,48 & 37,13 \\
\hline 2 & $\begin{array}{l}\text { Potential } \\
\text { area of GOS } \\
\text { at the border } \\
\text { of Railroad }\end{array}$ & 0,00 & 3,27 & 1,53 & 4,38 & 0,00 & 9,18 \\
\hline 3 & $\begin{array}{l}\text { Potential } \\
\text { area of the } \\
\text { river bendl }\end{array}$ & 0,00 & 0,62 & 0,00 & 10,82 & 0,30 & 11,74 \\
\hline 4 & $\begin{array}{l}\text { Potential } \\
\text { area of the } \\
\text { government } \\
\text { land }\end{array}$ & 0,00 & 17,82 & 18,82 & 22,02 & 13,79 & 72,45 \\
\hline 5 & $\begin{array}{l}\text { GOS based } \\
\text { on plan } \\
\text { space }\end{array}$ & 0,00 & 0,84 & 0,00 & 11,39 & 0,00 & 12,23 \\
\hline 6 & $\begin{array}{l}\text { Potential of } \\
\text { GOS in } \\
\text { open land }\end{array}$ & 0,40 & 4,45 & 1,64 & 89,00 & 0,24 & 95,75 \\
\hline & [otal (Ha) & 3,16 & 24,84 & 24,29 & 67,87 & 22,57 & $\begin{array}{c}238,4 \\
6\end{array}$ \\
\hline
\end{tabular}

Source: Hasil Analisa, 2018
Based on the results of the analysis that has been carried out, the results obtained from the total area of green open space that has the potential to be developed in Sub-district of Semampir are 238.46 Ha. The widest potential area of green open space is the potential for open land that has not been managed as green space for an area of 95.73 (40\%), while the second largest area is derived from government assets, covering an area of $72.45 \mathrm{Ha}(30 \%)$ and for the lowest area railway borders covering an area of 9.18 Ha (9\%). For more details can be seen in the picture below.

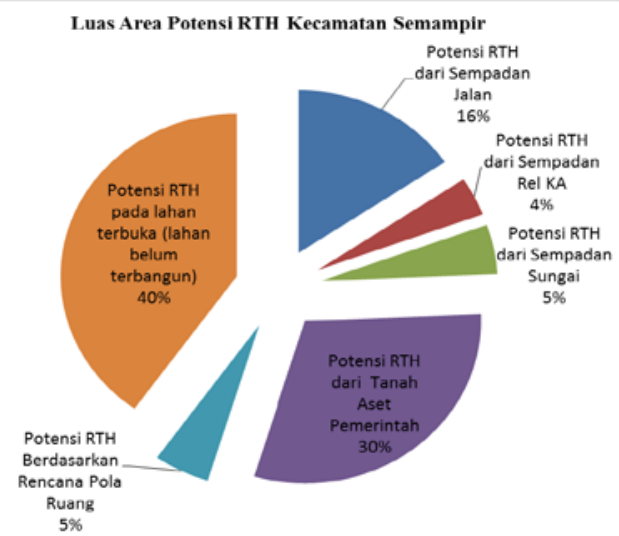

Fig 12. Area diagram of potential area of RTH in Semampir Subdistrict

Based on the results of the analysis done, will be described in more detail on each potential in the village.

1. GOS Potential of Road border.

The GOS potential of the road border in Sub-district of Semampir is $37.13 \mathrm{Ha}$, with the widest urban area of Ujung covering $19.26 \mathrm{Ha}$, and for the smallest area is Pegirian of $2.29 \mathrm{Ha}$.

2. The GOS Potential of the Railroad border.

The potential of open green space along the railroad in Subdistrict of Semampir is 9,18 Ha, with the widest urban area in Ujung covering 4,38 $\mathrm{Ha}$, and for Ampel and Wonokusumo have no border area.

3. The potential of GOS from River Border.

GOS potential from river border in Sub-district of Semampir is $11.74 \mathrm{Ha}$, with the widest urban area is Ujung covering $10.28 \mathrm{Ha}$, and for Ampel and Sidotopo has no river.

4. Potential of Land Government Green Land.

The GOS potential of government assets in Sub-District of Semampir is $72.45 \mathrm{Ha}$, with the widest urban area being Ujung of $22.02 \mathrm{Ha}$, and for areas with no assets of the government is Ampel.

5. GOS Based on Spatial Plan Plan

GOS Potential of Spatial Plan in Sub-District of Semampir is $12,23 \mathrm{Ha}$, with the widest area is Ujung of $11,39 \mathrm{Ha}$, and for an area not accommodated plan of the spatial pattern as green open space is Ampel urban village, Sidotopo, and Wonokusumo urban village .

6. GOS by Land of open land assets

GOS potential of open land asset land in Sub-district of Semampir is $95.73 \mathrm{Ha}$, with the widest urban area is Ujung of $89.00 \mathrm{Ha}$, and for an area with the lowest width of Wonokusumo with area $0,24 \mathrm{Ha}$. 


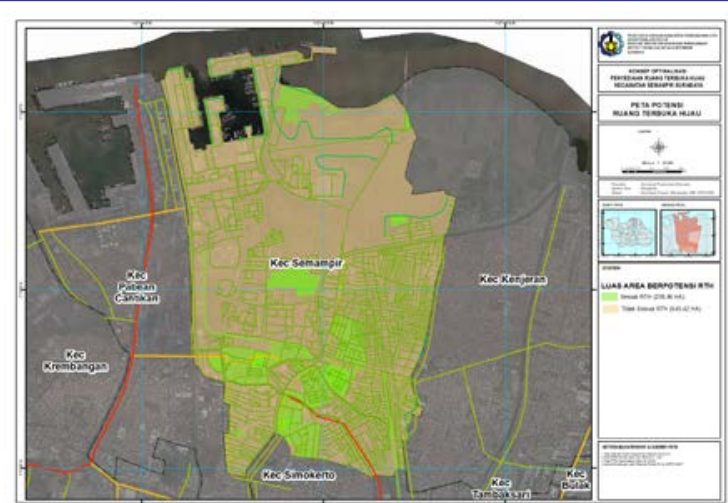

Fig 13. Map of GOS Potential Area in Semampir Subdistrict

So the area of potential land for GOS of 238.46 Ha or 26.95\% of the provisions of the regulation of Surabaya City No.12 of 2014 on RTRW which says that the area of Public Space 20\%, green open space in the Sub-District of Semampir has sufficient in accordance with the legislation applies.

\section{CONCLUSION}

The result of total green open space potential to be developed in Sub-district of Semampir is 238.46 Ha. The widest potential area of green open space is the potential of land for open land assets covering 95.73 На (40.15\%), while the second largest area is derived from the government assets of $72.45 \mathrm{Ha}(30.38 \%)$ and the lowest area is from the railroad area of $9.18 \mathrm{Ha}(3.84 \%)$. The potential land area for GOS is 238.46 Ha or $26.95 \%$ of the provisions of the Surabaya City Regulation No.12 of 2014 concerning the "RTRW" which says that the area of public GOS is $20 \%$ meaning that land needs for GOS have met the targets set by the City Government Surabaya.

\section{ACKNOWLEDGMENT}

Praise be to Allah and blessings and greetings to the Prophet Muhammad SAW's so that this journal could be finished well. Big gratitude to people who have helped in completing this journal, father, and mother, supervisors for the advice and input during the study, staff from across the district as a respondent that helped to provide the research data. Hopefully, this journal could provide benefits and new information to all parties.

REFERENCES

[1] Undang Undang (UU) Nomor 26 Tahun 2007 tentang penataan ruang

[2] Reksohadiprojo. 2001. Ekonomi Perkotaan. Edisi ke 4, BPFE-Yogyakarta.

[3] Peraturan Menteri Pekerjaan Umum No.20/Prt/M/2007 Pedoman Teknis Analisis Aspek Fisik dan Lingkungan, Ekonomi, Serta Sosial Budaya Dalam Penyusunan Rencana Tata Ruang

[4] Peraturan Daerah Surabaya No. 12 Tahun 2014 tentang Rencana Tata Ruang Wilayah Kota Surabaya Tahun 2014-2034

[5] Permen PU Nomor 5 Tahun 2008 tentang Pedoman Penyediaan dan Pemanfaatan Ruang Terbuka Hijau di Kawasan Perkotaan

[6] Dinas Lingkungan Hidup Kota Surabaya, 2014

[7] Data aset Dinas Pengelolan Bangunan dan Tanah Pemerintah Kota Surabaya, 2018

[8] Rencana Tata Ruang Wilayah Kota Surabaya Tahun 2012-2034 